\title{
como fazer amigos e influenciar pessoas
}

Mateus Raynner André de Souza

Hoje Não Garotos, Hoje Vamos à MISSA

Quero viajar, quero conhecer, quero saber mais, quero fazer mais, quero ser melhor. Quero divertir-me contigo, com ele, com ela e com os outros. Quero olhar para trás e pensar que valeu a pena tudo isto. Quero sentir a terra, o verde e o azu e o brancol.

Minha ocupação é te ver feliz, , gosto de te ver e sorrir, , faço tudo pra te ver alegre, , sou divertida e gosto de divertir os meus amigos,, sou bwe minha fã , eu me amo mas tambem te amo

eu queria dize que meu cargo neste emprego eh um lugar de alta imprortamsia pq eu trabalho muitas vezeses nesse lugar e eh o melhor lugar do mundo pq eh muito legal e eu sou o cara mais fda que trabalha neste lugar legal sou mt foda gente bjs tchau

Eu não tenho ensino superior. Acho que digitei errado. 
Eu ACREdito em Bruno Borges

Infelizmente a humanidade foi um erro

Por mim derrubava todos os presidente até colocar o louro josé lá

Glória Maria Espiã Sensual

Meooo isso é muito black mirror

Cenas de filmes desenhadas no paint

Bem aventurados os corações flexíveis, pois eles nunca se partirão. A vida é curta e os prazeres são raros;)))aquele toque no peito sempre!!!

passei muito tempo sem querer me emvouver com ninguem pq tinha medo de amar e nao ser conrrespondida so que agora eu amo muito uma pessoa qui ja nao sei ficar sem ele esse ve meu maior medo $\mathrm{q}$

Infelizmente arte é uma merda

Assim Como o Mar eu Também Tenho os Meus Dias De Revolta. 